TAHKIM, Jurnal Peradaban dan Hukum Islam. Vol.3 No.2 (0ktober, 2020) | ISSN : 2597-7962

\title{
TINJAUAN HUKUM ISLAM TERHADAP FASILITATOR PERBUATAN ZINA
}

\author{
Dudi Badruzaman \\ Program Studi Hukum Ekonomi Syari'ah Stai Sabili Bandung \\ badruzaman.dudi@yahoo.com
}

\begin{abstract}
ABSTRAK
Zina sekarang bukan sekedar perbuatan perseorangan lagi, tapi sudah menjadi "industri" dengan adanya lokalisasi baik legal maupun ilegal. Dalam hal ini banyak pelaku terlibat didalamnya seperti adanya germo, calo seks, penyedia tempat, tukang antar, dan lain sebagainya. Mereka dapat disebut sebagai fasilitator perbuatan zina/cabul, disamping pelaku zina itu sendiri. Kajian ini bertujuan untuk mengetahui pandangan fiqh jinayah terhadap fasilitator perbuatan asusila dan sanksi bagi mereka. Dengan menggunakan metode contentanalisys serta pendekatan yuridis-normatif terhadap berbagai data kualitatif berupa peraturan dan teori yang terkait dengan objek kajian, hasil kajian menunjukkan bahwa para fasilitator perbuatan zina merupakan perbuatan jarimah dan termasuk pada bagian jarimah ta'zir karena pada dasarnya ikut turut serta dalam jarimah zina dan memberikan bantuan dan kesempatan terjadinya perbuatan yang dilarang yaitu melakukan perbuatan cabul. Dilihat dari konsep turut serta, fasilitator perbuatan cabul ini termasuk pada turut serta secara tidak langsung dan bergantung pada kasusnya, bisa dengan jalan persepakatan, menghasut (menyuruh), atau memberi bantuan. Sanksi bagi fasilitator perbuatan zina ini adalah sanksi ta'zir, berat ringannya menjadi hak negara sesuai dengan tuntutan kemaslahatan.
\end{abstract}

Kata kunci: Hukum Islam, fasilitator, Zina.

\section{ABSTRACT}

Adultery is now not just an individual act anymore, but has become an "industry" with localization both legal and illegal. In this case many actors are involved in it such as the presence of pimps, sex brokers, providers of places, delivery people, etc. They can be referred to as the facilitator of adultery / obscenity, in addition to the adulterer itself. The purpose of this study is to find out the views of jurisprudence fiqh towards facilitators of assault and sanctions for them., this study shows that the facilitators of immoral acts are jarimah acts and are included in ta'zir jarimah's part. Judging from the concept of participation, the facilitator of obscene acts includes participating indirectly and depending on the case, can by way of agreement, inciting (ordering), or giving assistance. The sanction for the facilitator of this obscene act is the sanction of ta'zir, the light weight become state rights in accordance with the demands of benefit.

Keywords: Islamic Law, facilitator, Zina. 


\section{A. PENDAHULUAN}

Dahulu, membicarakan masalah seks dianggap tabu. Namun saat ini hal tersebut sudah lumrah dan sering dibahas di berbagai media massa dan sosial. di majalah, surat kabar harian, radio, dan sejenisnya telah banyak dibahas tentang seks. Misalnya, terbitnya majalah Play Boy yaitu majalah versi Amerika Serikat yang dipenuhi gambar wanita setengah telanjang, menampilkan aurat secara vulgar, cerita-cerita petualangan seks, free sex, dan sejenisnya. Dengan hal ini, akan merusak cara pandang Indonesia terhadap persoalan seks, persis seperti perspektif barat yang menghalalkan seks tanpa batas. ${ }^{1}$

Menurut An-Nadwi yang dikutip olej Adian Husain“...peradaban Barat adalah kelanjutan peradaban Yunani yang telah mewariskan kebudayaan politik, pemikiran, dan kebudayaan.Kebudayaan Yunani yang telah menjadi peradaban Barat, memiliki sejumlah keistimewaan yakni menjungjung tinggi kehidupan duniawi dan menaruh perhatian yang berlebihan terhadap manfaat dan kenikmatan hidup.Kenikamatan dalam bentuk apapun harus diraih tanpa batas, apakah itu materi, jabatan, kekuasaan seks, homoseks, lesbianisme, popularitas dan lain sebagainya. ${ }^{2}$

Akibatnya, masyarakat Indonesia tidak lagi berpegang pada "spiritualitas, mentalitas, dan moralitas".Mereka semakin cinta buta dan fanatik terhadap budaya Barat yang menjanjikan kebanggaan, keglamoran, kemewahan, kenikmatan, dan kejayaan duniawi. Adalah awal malapetaka agama dan bangsa ini.Globalisasi itulah media efektif yang digunakan Barat untuk menjajah negara berkembang dan negara lemah, khususnya negara-negara Islam. ${ }^{3}$

Contoh kecil dari pengaruh budaya Barat terhadap Indonesia antara lain keengganan penginapan untuk menanyakan identitas tamu/pelanggan sebagai bentuk perlindungan privasi tamu dan pelayanan, serta prinsip pembeli adalah raja. Peluang tersebut kemudian disalahgunakan oleh anggota masyarakat untuk melakukan perbuatan maksiat, seperti menyediakan pekerja seks bagi para tamu. Seseorang disebut sebagai

\footnotetext{
${ }^{1}$ Jamal, Hukum Pidana 3 :bagian Khusus Delik-delik Khusus (Bandung:Binacipta, 2009), hlm.178. ${ }^{2}$ R.Soeroso, Pengantar Ilmu Hukum. (Jakarta: Sinar Grafika,2006), hlm. 120.

${ }^{3}$ Sulaiman Rasjid, Fiqh Islam. (Jakarta: Attahiriyah, 1979) hlm.85.
} 
pekerja seks ketika adanya transaksi uang atau imbalan, dan sering melibatkan kontrol dari seorang germo atau calo seks.Istilah yang paling dikenal dalam masyarakat adalah wanita tuna susila (WTS) atau pelacur. ${ }^{4}$

Calo seks adakalanya tukang taksi yang mengetahui benar lokasi-lokasi pelacuran, bisa juga laki-laki biasa yang mengantarkan wanita tersebut menuju pelanggannya.Calo seks dapat pula mereka yang merekrut calon-calon pelacur muda yang didapatnya di kampung-kampung, mengiming-ngiming mereka dengan pekerjaan di kota padahal dijual ke germo.

Germo adalah sebagai pengasuh atau penampung para pelacur. Biasanya para pelacur itu dalam satu rumah kos. Germo ini umumnya sudah memiliki pelanggan atau kerjasama dengan hotel, motel, atau tempat-tempat penginapan tertentu. Sebagian besar mereka hanya menjadikan para pelacur itu sebagai sapi perah.Si pelacur bekerja keras, germo yang menikmati uangnya. Adakalanya si pelacur dibuang begitu saja ketika sudah terlalu tua atau tertular penyakit kelamin. Tidak sedikit diantara mereka menjerumuskan anak dibawah umur dan keperawanannya dijual mahal kepada pelanggannya. Calo seks atau germo tergolong manusia terkutuk, mereka telah menjadi jalan bagi orang lain untuk berbuat maksiat. ${ }^{5}$

Contoh kasus, di Bandung, Jawa Barat, seorang PNS tertangkap basah oleh aparat sedang melakukan hubungan intim di salah satu Hotel di kawasan Jatinangor Bandung. Pada saat itu, petugas sedang melakukan razia dihotel tersebut karena banyak laporan dari masyarakat setempat bahwa hotel tersebut sering dijadikan ajang untuk prostitusi. Saat akan di gelandang oleh petugas ke kantor polisi, oknum PNS tersebut mengelak dan menolaknya dengan alasan mereka adalah suami istri. Akan tetapi, pernyataan itu palsu karena mereka tidak memiliki surat kawin dan identitas yang jelas ${ }^{6}$

Berdasarkan pengakuan pasangan tersebut saat di wawancara kepada tamu hotel dan wanita penghiur tersebut selaku petugas, keduanya dipertemukan oleh pihak hotel sebagai bentuk pelayanan dari pihak hotel untuk para tamunya, yaitu dengan menyediakan wanita penghibur. Ketika ditanya oleh pihak petugas terhadap wanita

\footnotetext{
${ }^{4}$ Soejono soekanto, Pengantar Penelitian Hukum, (Jakarta:UI-pres, 1996), hlm. 85.

${ }^{5} \mathrm{Al}$-Mawardi, Al Ahkam Al Shulthaniyyah,(Beirut: Dar Al Fikr,1966), hlm. 204.

${ }^{6}$ Pikiran Rakyat, 1 Desember 2007:14.00 Wib.
} 
TAHKIM, Jurnal Peradaban dan Hukum Islam. Vol.3 No.2 (0ktober, 2020) | ISSN : 2597-7962

penghibur itu, sudah lama kerja di Hotel tersebut. Ia di bayar oleh pihak hotel sebesar Rp 500 ribu sampai 1 juta /malam. Uang tersebut sudah bersih masuk ke kantongnya, karena sudah termasuk potongan dari pihak pemilik hotel. ${ }^{7}$

Ketika diwawancara terhadap karyawan hotel, mereka tidak mengetahui bahwa dihotel tempat ia bekerja, karena setiap para tamu yang datang ke hotel ini, ketika bawa pasangan mereka mengakunya sebagai pasangan suami istri dan kami pun percaya tentang hal itu. Demikian, keterangan dari beberapa karyawan hotel itu.

Namun saat ditelusuri oleh petugas, ternyata di dalam hotel itu bekerja sama dengan pemilik para wanita penghibur tersebut. Dan hasilnya dibagi dua antara pemilik hotel dengan pemilik para wanita-wanita penghibur.Dengan hal itu, pihak kepolisian segera mencari pihak-pihak yang bersangkutan untuk diamankan.

Atas perbuatannya tersebut, tersangka dijerat dengan pasal 296 Kitab Undangundang Hukum Pidana (KUHP), tentang fasilitator perbuatan cabul dengan ancaman hukuman maksimal 1 tahun empat bulan penjara atau pidana denda Rp.15.000, sebagaimana disebutkan bahwa: "Barang siapa dengan sengaja menyebabkan atau memudahkan perbuatan cabul dengan orang lain, dan menjadikannya sebagai pencaharian atau kebiasaan, diancam dengan pidana penjara paling lama satu tahun empat bulan atau pidana denda paling banyak lima belas ribu rupiah."

Unsur-unsur dalam Pasal 296 KUHP tersebut di atas yaitu menyediakan tempat dan mengorganisir PSK untuk praktek prostitusi dengan tujuan bisnis, melakukan perbuatan yang bertentangan dengan hukum, agama dan moral sehingga dapat merusak moral, mental dan keutuhan keluarga. ${ }^{8}$

Menurut Dede Rosada perzinahan diharamkan oleh syari'at Islam karena menghancurkan garis keturunan dan putusnya hak waris, mengakibatkan kehamilan sehingga anak yang terlahir tersia-sia dari pemeliharaan, pengurusan dan pembinaan

\footnotetext{
${ }^{7}$ Wawancara tanggal 15 desember 2019, pukul 13.00.

8 Dudi Badruzaman, Kajian Hukum Tentang Internet Mobile dalam Upaya Pencegahan Dampak Negatif Teknologi Informasi dan Komunikasi di Indonesia. Ajudikasi: Jurnal Ilmu Hukum, 3(2) (2019).
} Hlm. 135-152. 
TAHKIM, Jurnal Peradaban dan Hukum Islam. Vol.3 No.2 (0ktober, 2020) | ISSN : 2597-7962

pendidikannya, merupakan salah-satu bentuk dari prilaku binatang yang akan menghancurkan kemanusiaan, menimbulkan penyakit yang berbahaya dan menular. ${ }^{9}$

Dalam al-Quran, sanksi zina diterangkan dalam Surat An-Nur ayat (2) berikut:

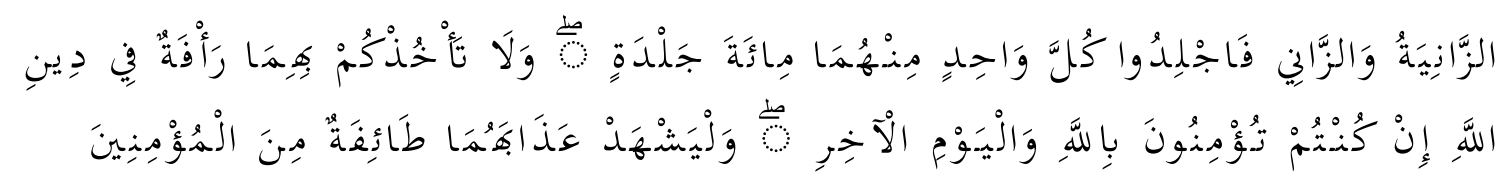

"Perempuan yang berzina dan laki-laki yang berzina, Maka deralah tiap-tiap seorang dari keduanya seratus dali dera, dan janganlah belas kasihan kepada keduanya mencegah kamu untuk (menjalankan) agama Allah, jika kamu beriman kepada Allah, dan hari akhirat, dan hendaklah (pelaksanaan) hukuman mereka disaksikan oleh sekumpulan orang-orang yang beriman."

Berdasarkan latar belakang diatas, tulisan ini menjabarkan pandangan fiqh jinayah terhadap fasilitator perbuatan asusilaserta sanksi bagi mereka.

\section{B. METODE PENELITIAN}

Metode yang digunakan dalam penelitian ini adalah metode content analisys (analisis isi), yaitu suatu metode penelitian pemikiran yang bersifat normatif. ${ }^{10}$ Pendekatan yang digunakan dalam penelitian ini adalah pendekatan Yuridis Normatif mengkaji kaidah-kaidah hukum yang sedang berlaku. ${ }^{11}$ Penentuan jenis data yang digunakan dalam penelitian tentang tinjauan fiqh jinayah terhadap fasilitator perbuatan asusila adalah jenis data kualitatif yaitu data tentang tindak pidana fasilitator perbuatan asusila, teori-teori sanksi tentang masalah yang berhubungan dengan perbuatan cabul dan pelacuran.

Data-data yang dipakai dalam penelitian ini meliputi data primer dan data skunder. (a) Data primer, Yaitu bahan hukum yang mengikat yang terdiri dari buku-buku

\footnotetext{
${ }^{9}$ Dede Rosyada, Hukum islam Dalam Pranata Sosial, (Jakarta :Rajawali Pers, 1995), hlm. 88.

${ }^{10}$ Cik Hasan Basri, Penuntun Penyusunan Rencana Penelitian dan Penulisan Skripsi (Bidang Ilmu Agama Islam). Jakarta: PT. Raja Grafindo Persada, 2008) hlm. 60. hlm.60.

${ }^{11}$ Hilman Hadikusuma, Hukum Adat Dalam Yurisprudensi, (Jakarta: cv Mandar Maju, 1995),
} 
fiqh jinayah dan buku-buku lainnya, seperti: filsafat hukum islam, hukum islam dan pranata sosial. (b) Data skunder yaitu kitab-kitab dan buku-buku yang relevan dengan masalah yang diteliti yang menunjang seperti KUHP. ${ }^{12}$ Teknik pengumpulan data yang diperlukan dalam penelitian ini adalah study kepustakaan yaitu mempelajari buku-buku yang berhubungan dengan masalah yang di bahas. Untuk mengetahui hubungan data yang telah diperoleh maka diperlukan analisis data menggunakan data sebagai berikut: (a) Mengumpulkan data yang diperlukan seperti, teori-teori yang berkaitandengan pelacuran atau perzinahan. (b) Mengklasifikasikan data baik dari bahan hukum primer maupun bahan hukum skunder sesuai dengan permasalahan yang diajukan. (c) Menganalisa dan menyimpulkan hasil data yang telah diklasifikasi berdasarkan permasalahan yang diajukan guna meraih tujuan yang ingin dicapai penulis dalam penelitian ini.

\section{PEMBAHASAN}

\section{Sanksi terhadap fasilitator perbuatan zina dalam hukum islam}

Pada dasarnya perbuatan memfasilitasi terjadinya tindak pidana (jarimah) dalam persepektif hukum khususnya dalam hukum Islam tetap terkena sanksi sesuai dengan tingkat berat dan ringannya tindak pidana yang pokok. Menurut A. Dzajuli dari segi berat ringannya hukuman, jarimah terbagi ke dalam tiga macam, yaitu: jarimah hudud, jarimah qishash dan diyat, serta jarimah ta'zir. ${ }^{13}$

Pertama, Jarimah hudud, yaitu jarimah yang diancam dengan hukuman had, yang telah ditentukan hukumannya oleh syara dan menjadi hak Allah, dalam jarimah ini tidak ada pemaafan. Kedua, Jarimah qishash dan diat adalah jarimah yang diancam dengan hukuman qishash atau diat. Yang termasuk pada jarimah ini adalah pembunuhan dan penganiayaan. Ketiga, Jarimah ta'zir adalah jarimah yang tidak ada keteta pannya oleh syara tetapi diserahkan kepada ulil amri baik ketentuannya maupun pelaksanaannya.

Dari pengertian jarimah di atas, perbuatan yang berhubungan dengan zina, misalnya fasilitator perbuatan tersebut, dalam persfektif fiqh jinayah tergolong ke dalam jarimah ta'zir. Dengan demikian, pelaku perzinaan lebih-lebih pelacuran mendapat hukuman

\footnotetext{
${ }^{12}$ Soejono soekanto, Pengantar Penelitian Hukum Jakarta:UI-pres, 1996), hlm. 76.

${ }^{13}$ A.Djazuli,imu fiqh (Sebuah Pengantar). (Bandung :Orba, sakti,1993), hlm. 13.
} 
yang tegas dan keras, yakni hukuman rajam (zina muhshan) atau deraan (zina ghaer muhshan). Sementara bagi yang tidak terlibat langsung, seperti sanksi bagi para pelantara, germo, mucikari, penyedia tempat dan fasilitator lainnya, maka hukumannya dapat pula ditentukan oleh yang berwenang. Menurut Hukum Pidana Islam, misalnya, sanksi untuk para pelaku seperti itu dapat di berlakukan sanksi ta'zir dengan kadar hukuman mulai dari yang teringan sampai terberat sesuai dengan ringan atau berat tindak kejahatannya. Hukuman ini berdasarkan atas dalil umum dari Al qur'an Surat Al Isra ayat (32):

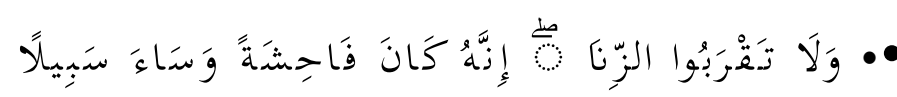

Artinya:

"Dan janganlah kamu mendekati zina, sesungguhnya zina itu adalah suatu perbuatan yang keji, dan suatu jalan yang buruk.“

Berpijak pada pemikiran bahwa setiap masalah yang lepas daripada faktor lain (qarenah) dari suatu larangan, maka larangan tersebut mengandung tuntutan yang hakiki yaitu haram, sebagaimana firman Allah SWT dalam Surat Al Isra ayat 32 berikut:

\section{"Dan janganlah kamu mendekati zina"}

Jika kalimat itu mempunyai qarenah, tidak menunjukan hakikat larangan. Kalimat larangan tersebut lebih menunjukkan makna antisipatif dan preventif ketimbang larangan “janganlah kamu zina” janganlah kamu mendekati zina berarti larangan pula terhadap segala hal yang membuka terjadinya zina, termasuk menyediakan tempat atau fasilitas lain yang mempermudah bahkan mendukung terjadinya perbuatan asusila tersebut. Banyak sekali contoh kasus yang mempermudah dan mendorong seseorang untuk melakukan perbuatan zina seperti contoh kasus anak-anak remaja mulai SMA, kuliah, mayoritas mereka berpacaran, biasanya selama mereka pacaran, makan bersama, nonton film bersama, sekali dua kali berani memegang tangan, mencium, meraba, dan akhirnya terjadilah perzinaan. Oleh karena itu dalam Islam tidak dikenal istilah pacaran, laki-laki mencintai perempuan juga sebaliknya perempuan mencintai laki-laki merupakan 
TAHKIM, Jurnal Peradaban dan Hukum Islam. Vol.3 No.2 (0ktober, 2020) | ISSN : 2597-7962

sunatullah kepada manusia yang tidak bisa diubah, disanalah disyariatkan umat Islam untuk melangsungkan pernikahan. ${ }^{14}$

Jarimah ta'zir adalah jarimah yang sanksi hukumannya tidak dijelaskan secara langsung (eksplisit) sebagaimana dalam kedua jarimah lainnya, tetapi ketetapan dan kepastian kadar hukumannya diserahkan kepada hakim atau penguasa. ${ }^{15}$

Menurut A, Dzajuli, pelaksanaan jarimah ta'zir harus mempertimbangkan banyak aspek. Dalam menentukan sanksinya harus mempertimbangkan antara lain kondisi pelaku baik fisik maupun kejiwaan serta, motif tindakannya tersebut. Sehingga sanksi yang dijatuhkannya variatif sesuai dengan rasa keadilan. Misalnya, untuk menjerakan si pelaku sudah tentu tidak harus sama antara orang yang satu dengan orang yang lainnya seperti dengan deraan, ada yang harus dikurung, dan sebagainya. ${ }^{16}$

Bentuk sanksi ta'zir, diantaranya adalah: ${ }^{17}$ (a) sanksi ta'zir yang mengenai badan, hukuman yang terpenting dalam hal ini adalah hukuman mati dan jilid; (b) sanksi yang berkaitan dengan kemerdekaan seseorang, antara lain penjara dengan berbagai macamnya dan pengasingan. (c) Sanksi ta'zir yang berkaitan dengan harta, dalam hal ini yang terpenting di antaranya adalah denda, penyitaan/perampasan dan penghancuran barang. (d) Sanksi-sanksi lainnya yang ditentukan oleh Ulil Amri demi kemaslahatan umum.

Larangan perzinaan sama kerasnya dengan larangan terhadap pembunuhan dan termasuk dosa besar sebagaimana dijelaskan dalam al Qur'an surat Al- furqon ayat (6869) berikut:

"Dan orang-orang yang tidak menyembah Tuhan yang lain beserta Allah dan tidak membunuh jiwa yang diharamkan Allah (membunuhnya) kecuali dengan (alasan) yang benar, dan tidak berzina, barang siapa yang melakukan yang demikian itu, niscaya Dia mendapat (pembalasan) dosa (nya),(yakni) akan dilipat

${ }^{14}$ Zainuddin Ali, Hukum Pidan Islam. (Jakarta :Sinar Grafika, 2009)Hlm: 159.

${ }^{15}$ Jaih Mubarok dan Enceng Arif Faizal,Kaidah Fiqh Jinayah (Asas-Asas Hukum Pidana Islam). (Bandung :Pustaka Bani Quraisy,2005) hlm, 54.

${ }^{16}$ A.Djazuli, imu fiqh Sebuah Pengantar. (Bandung :Orba sakti, 1993) hlm: 219.

${ }^{17}$ Ibid., hlm, 159. 
TAHKIM, Jurnal Peradaban dan Hukum Islam. Vol.3 No.2 (0ktober, 2020) | ISSN : 2597-7962

gandakan azab untuknya pada hari kiamat dan Dia akan kekal dalam azab itu, dalam Keadaan terhina."

Lebih rincinya sanksi zina diterangkan dalam Surat An Nur ayat (2) berikut:

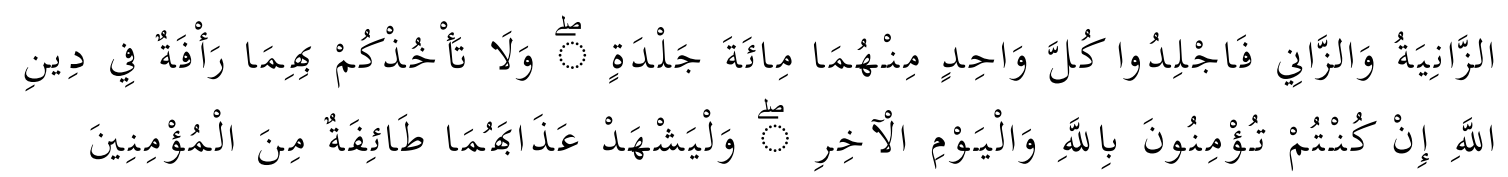
Artinya:

“ Perempuan yang berzina dan laki-laki yang berzina, Maka deralah tiap-tiap seorang dari keduanya seratus dali dera, dan janganlah belas kasihan kepada keduanya mencegah kamu untuk (menjalankan) agama Allah, jika kamu beriman kepada Allah, dan hari akhirat, dan hendaklah (pelaksanaan) hukuman mereka disaksikan oleh sekumpulan orang-orang yang beriman."

Ayat tersebut menunjukan larangan sangat keras dan tegas bahwa perbuatan zina adalah haram.Ketetapan hukum ini tidak diperselisihkan ulama, Nampak jelas, perbuatan zina diharamkan karena termasuk perbuatan buruk dan keji. Begitu pula cara yang ditempuh perzinahan merupakan cara yang buruk. Karena itu, menetapkan cara penyaluran nafsu syahwat terbaik melalui pernikahan.

Syari'at Islam sangat serius mnghadapi masalah zinadan menempatkannya kepada masalah sosial.Para pelakunya dinyatakan sebagai pelaku kejahatan umum oleh publik.Oleh karena itu, mereka di tuntut oleh para penuntut umum yang mewakili masyarakat.Hal ini berbeda dengan system hukum barat dimana zina hanya termasuk masalah pribadi. Sikap tegas dan kerasnya syari'at islam tehadap perbuatan zina dibuktikan dengan hukuman yang ditetapkannya sangat berat yaitu hukuman mati sebagai hukum tertinggi dan hukuman dera 100 kali sebagai hukuman terendah.

Ancaman hukuman tersebut di atas baru dilakukan jika terdapat bukti-bukti yang meyakinkan dan diyakini bahwa dalam hubungan tersebut tidak terdapat unsur-unsur kesamaran atau subhat.Pembuktian tersebut berlaku dengan adanya kesaksian dari empat orang laki-laki muslim yang adil dan dapat dipercaya, serta keempatnya secara meyakinkan melihat langsung hubungan kelamin itu bersamaan. Bila kriteria tersebut 
TAHKIM, Jurnal Peradaban dan Hukum Islam. Vol.3 No.2 (0ktober, 2020) | ISSN : 2597-7962

tidak terpenuhi, maka kesaksian tersebut tidak sah. Hal tersebut sesuai dengan firman Allah dalam Al qur'an Surat An Nisa ayat (15):

"Dan (terhadap) para wanita yang mengerjakan perbuatan keji hendaklah ada empat orang saksi diantara kamu (yang menyaksikannya).kemudian apabila mereka telah memberi persaksian, Maka kurunglah mereka (wanita-wanita itu) dalam rumah sampai mereka menemui ajalnya, atau sampai Allah memberi jalan lain kepadanya."

Menurut jumhur mufassirin, yang dimaksud perbuatan keji dalam ayat tersebut adalah perbuatan zina.Adapun pendapat lain menyatakan bahwa yang termasuk perbuatan keji tersebut adalah setiap perbuatan asusila, seperti zina, homoseks, dan yang sejenisnya. Sedangkan Muslim dan Mujahid mengaitkan perbuatan tersebut dengan musahaqah (homoseks antara wanita dengan wanita). ${ }^{18}$

Dan firman Allah dalam Surat An Nur ayat (4):

"Dan orang-orang yang menuduh wanita-wanita yang baik-baik, (berbuat zina) dan mereka tidak mendatangkan empat orang saksi, Maka deralah mereka (yang menuduh itu) delapan puluh kali dera, dan janganlah kamu terima kesaksian mereka buat selama-lamanya.dan mereka Itulah orang-orang yang fasik."

Perzinaan adalah kejahatan yang memalukan dan termasuk dosa besar.Bila perzinaan itu dilemparkan kepada seseorang secara fitnah berarti mendatangkan malu besar atau penghinaan kepada orang yang dituduh.Harga diri itu termasuk salah satu sendi kehidupan manusia.Hal itu disebut kejahatan yang dilarang Allah dan termasuk perbuatan maksiat yang diancam dengan dosa di akhirat dan hukuman di dunia.

\section{Analisis terhadap fasilitator perbuatan zina dalam fiqh jinayah.}

Sebagaimana telah dijelaskan pada uraian sebelumnya, bahwa secara umum perbuatan cabul adalah perbuatan yang bertentangan dengan adat kesopanan, keadaban, sopan santun, dan ketertiban, atau kepatutan-kepatutan lainnya.Lalu kata cabul tersebut

${ }^{18}$ Badruzaman, D., \& Ropei, A. (2020). Gender Equality For Women Victims Of Violence In Household. Al-IHKAM: Jurnal Hukum Keluarga Jurusan Ahwal Al-Syakhshiyyah Fakultas Syariah IAIN Mataram, 12(1),Hlm. 1-14. 
TAHKIM, Jurnal Peradaban dan Hukum Islam. Vol.3 No.2 (0ktober, 2020) | ISSN : 2597-7962

direduksi maknanya (dipersempit) menjadi perbuatan yang berkenan dengan moral seseorang, yaitu perbuatan yang berdasarkan pada pertimbangan nilai baik dan buruknya yang telah diatur dalam undang-undang yang berlaku (hukum positif). Bahkan secara leksikal, kata cabul lebih khusus dioprasionalkan untuk perbuatan yang berkaitan dengan seks semata yang bertentangan dengan hukum yang berlaku. Begitu pula halnya, yang dapat membuka kesempatan atau menjadi fasilitator perbuatan asusila misalnya: menyediakan tempat untuk teerjadinya perbuatan cabul, maka dalam perspektif fiqh jinayah, bagi kasus seperti ini masih dimungkinkan diberi ketepatan hukumannya yaitu berupa hukuman ta'zir.

Hukuman bagi fasilitator perbuatan asusila bila dilihat relevansinya menurut fiqh jinayah, dapat ditetapkan hukumannya oleh para hakim atau pihak yang berwenang berdasarkan berbagai pertimbangan, baik secara normatif maupun pertimbangan tujuan tujuan hukum pidana Islam.

\section{Pertimbangan yang pertama adalah pertimbangan normatif}

Yang dimaksud pertimbangan normatif di sini adalah pertimbangan yang bersumber kepada norma hukum ideal yang berlaku dinegara Indonesia dan juga normanorma agama Islam. Terutama norma-norma keimanan yang datang dari Tuhan.Karena itu, menurut Bismar Siregar, berbicara tentang landasan Hukum Pidana sudah seharusnya ( kalimat beliau" tidak boleh tidak wajib"). Oleh karena itu, umat Islam wajib membuktikan rasa syukurnya melebihi para penganut agama dan kepercayaan yang lain. Umat Islam menyadari apa, dimana dan bagaimana, bila berbicara tentang hukum harus ada rujukan. Pertama wahyu Ilahi yang dihimpun dalam kitab Al Qur'an, kedua sunah Rasulullah. Keharusan ini bila bertentangan bahkan ada relevansinya dengan kewajibannya sebagai warga Negara Indonesia, sebab menurut penjelasan Pasal 1 daru UUD 1945 sendiri bahwa “ Negara Berdasarkan Ketuhanan Yang Maha Esa” maka makna sederhananya dapat dipahami bahwa apapun yang ada dan diadakan dinegara ini tidak boleh bertentangan dengan ke-Tuhanan Yang Maha Esa, dan bahwa nyatanya dan masih ada dan akan terus ada. Karena itu, secara Islami, tantangan menegakan yang hak dan menumpas yang batil, Amar Ma'ruf dan Nahyil Munkar wajib ditingkatkan.Salah 
satu yang harus ditingani adalah masalah kesusilaan. ${ }^{19}$

Menurut Bimar Siregar, Islam menentukan dengan sangat sederhana bahwa kejahatan kesusilaan merupakan kejahatan yang sangat peka, sehingga kalau memang terbukti dan diajukan di muka hakim, hukumannya keras dan tegas, karena berkenaan dengan harkat dan harga diri serta kehormatan manusia. Pada dasarnya menurut hemat penulis, ayat-ayat tersebut berkenaan langsung dengan pelaku perzinaan lebih-lebih pelacuran, sementara bagi yang tidak terlibat langsung, seperti bagaimana sanksi hukuman bagi bagi para pelantara, germo,mucikari, penyedia tempat dan fasilitator perbuatan asusila, maka hukumannya dapat pula ditentukan oleh yang berwenang. Menurut hukum pidana Islam, misalnya, sanksi untuk para pelaku seperti itu dapat diberlakukan sanksi ta'zir dengan kadar hukuman mulai yang teringan atau berat kejahatannya.

\section{Pertimbangan yang kedua yaitu tujuan hukum islam}

Dengan merujuk pendapat Al Syatibi, Fathurrahman Djamil mengatakan bahwa tujuan Allah mensyari'atkan hukum-Nya, adalah untuk memelihara kemaslahatan sekaligus untuk menghindari mafsadat, baik di dunia maupun diakhirat. Tujuan tersebut hendak dicapai melalui taklif, yang pelaksanaannya tergantung pada, pemahaman sumber hukum yang utama, al Qur'an dan Hadist. Hasil penelitian atas kedua sumber tersebut menunjukkan adanya lima unsur pokok (al-kuliyyat al-khams) yang harus dipelihara dan diwujudkan, yaitu: unsur agama, jiwa, akal, keturunan, dan harta. Apabila kelima unsur ini dipelihatkan, maka seorang mukallaf akan memperoleh kemaslahatan, dan begitu pula sebaliknya. ${ }^{20}$

Dilihat dari penting atau tidaknya, maka kelima unsur pokok tersebut dapat distratifikasikan menjadi tiga (3) tingkatan, yaitu: (1) yang bersifat dhaduriyyat, (2) hajiyyat, (3) tahsiniyyat.

Dharuriyat ialah tingkat kebutuhan yang harus ada atau disebut dengan kebutuhan primer. Bila tingkat ini tidak dipenuhi, akan terancam keselamatan manusia, baik di dunia maupun diakhirat kelak.Hajiyat kebutuhan-kebutuhan skunder. Bila kebutuhan ini tidak

\footnotetext{
${ }^{19}$ Toto Santoso, Menggagas Hukum Pidana Islam(Bandung: t.tp. 2007).jilid 2,hlm. 208

${ }^{20}$ Fathurrahman Djamil,Filsafat Hukum Islam .(Ciputat: Logos Wacana Ilmu,1997) hlm. 143.
} 
terwujud, maka tidak akan mengancam keselamatan manusia tetapi akan menimbulkan kesulitan. Padahal syari' at Islam berprinsip menghilangkan segala kesulitan. Sedangkan yang dinamakan tahsiniyatadalah kebutuhan yang tidak akan mengancam eksistensi kebutuhan pokok dan tidak pula kebutuhan sekunder (hilangnya kesulitan), tetapi ia hanya bersifat kelayakan-kelayakan /kepatutan menurut adat istiadat. ${ }^{21}$

Berdasarkan pertimbangan tujuan hukum Islam tentang unsur atau kebutuhan pokok dalam memelihara keturunan atau kehormatan (hifdzu an-nasal/hifdzu al-irdi) dimana salah satu perlindungan hukumnya adalah larangan zina dan hal-hal lain yang terkait dengannya, maka segala bentuk perbuatan atau tindak pidana yang secara langsung atau tidak langsung berhubungan dengan perzinaan adalah dilarang karena bertentangan dengan tujuan hukum Islam sendiri. Karena itu fasilitator perbuatan cabul sudah sepatutnya mendapat hukuman yang tidak jauh berbeda dengan hukuman zina itu sendiri melalui keputusan hukum dari yang berwenang.karena itu, sanksi bagi fasilitator perbuatan cabul yaitu dengan ta'zir. Dalam hal ini, tujuan hukum Islam sendiri yaitu terpeliharanya kemaslahatan hidup manusia.

Di samping itu, sanksi hukuman bagi fasilitator dalam perbuatan cabul bisa sama beratnya dengan pelaku utama berdasarkan kaidah yang berbunyi:

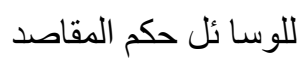

"Wasilah-wasilah itu memiliki hukum yang sejalan dengan hukum tujuannya".

Penulis memahami maksud kaidah tersebut dalam pengertian bahwa sanksi bagi siapapun yang memfasilitasi terjadinya perbuatan cabul adalah sama dengan jenis atau tingkat sanksi perbuatan cabul itu sendiri. Lebih-lebih segala hal yang mempercepat dan mempermudah terjadinya perbuatan cabul, sudah barang tentu mendapat sanksi yang tegas dan keras. Hal ini sebagaimana disampaikan oleh Izzuddin bin Abdissalam dalam kitabnya, “ Qawa'id al-Ahkam li mashalih al-anam " sebagai berikut:22

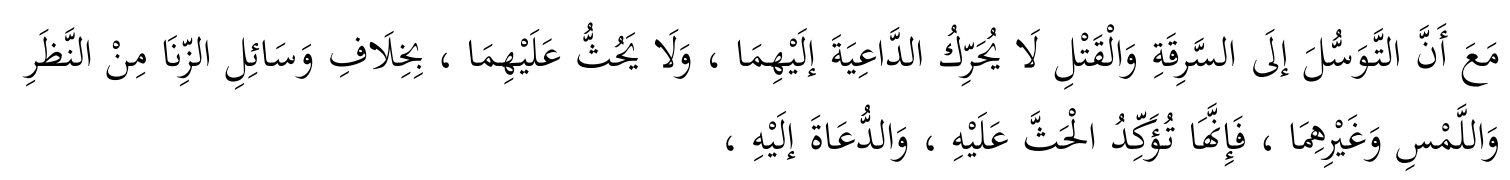

\footnotetext{
${ }^{21}$ Satria Effendi, Ushul Fiqih (Jakarta:Kencana, cetakan 1, 2005) hlm. 235.

${ }^{22}$ Ibnu Qadamah, Al mugni (Beirut: dar al manar,1368)( t.th. juz 1: 54)
} 
Teks tersebut menjelaskan bahwa tentang kemaslahatan dan kemafsadatan terdapat maksud/tujuan dan wasilah.Begitu pula yang berkenaan dengan hal-hal yang dimakruhkan dan diharamkan, maka di dalamnya terdapat tujuan dan wasilah.Status hukum wasilah tergantung tujuannya. Suatu wasilah menjadi tinggi kedudukannya bila tujuannya itu tinggi pula, dan sebaliknya ia menjadi rendah (termasuk sanksinya) bila berkenaan dengan rendahnya tujuan itu sendiri. Begitulah seterusnya status wasilah mengikuti tujuannya dalam kadar maslahat atau mafsadatnya suatu perbuatan.

Memandang wanita lain adalah haram karena akan membuka jalan (wasilah) berbuat zina, apalagi bila berduaan di tempat sepi dan apalagi bila sambil memeluknya. Lebih-lebih bila sampai duduk di atas kedua kakinya (posisi berzina), maka hal ini seburuk-buruk hal-hal (wasilah) perzinahan.Dengan demikian, tingkatan status hukum wasilah sangat tergantung kepada tingkat mafsadat itu sendiri. Ketika suatu wasilah terjadinya suatu mafsadat (perbuatan cabul, misalnya) semakin mendorong, maka dosanya dan tentu sanksinya pula akan semakin besar pula.

Demikianlah kedudukan sanksi pidana Islam terhadap fasilitator terjadinya perbuatan cabul dengan memperhatikan berbagai aspek sehingga hukumannya masuk ke dalam wilayah hukum ta'zir yang memiliki fleksibilitas antara hukuman maksimal dan minimal sesuai dengan tingkat madaratnya bagi individu dan umat.

\section{SIMPULAN}

Fasilitator perbuatan zina, dalam fiqh jinayah dianggap sebagai jarimah tidak langsung, yaitu memberikan bantuan kepada orang lain yang akan melakukan perbuatan zina, Seperti memberi tempat persembunyian, calo seks, dan yang mengantarkannya. Dengan demikian, seseorang yang memfasilitasi perbuatan cabul dianggap sebagai orang yang berbuat jarimah sebab secara yuridis formal ia telah melakukan yang sifatnya memberikan dorongan dan bantuan untuk melakukan perbuatan cabul tersebut.

Sanksi terhadap fasilitator perbuatan zina perspektif hukum islam termasuk dalam ta'zir, karena pada dasarnya ikut turut serta dalam jarimah zina dan memberikan bantuan dan kesempatan terjadinya perbuatan yang dilarang yaitu melakukan perbuatan cabul. Dalam fiqh jinayah turut berbuat jarimah tidak langsung bisa terjadi dengan jalan: (a) 
Persepakatan, yaitu adanya saling memahami dan karena kesamaan kehendak untuk memperbuat jarimah. (b) Menghasut, yaitu membujuk dan pendorong orang lain untuk diperbuatnya jarimah. (c) Memberi bantuan, yaitu memberikan bantuan kepada orang lain dalam memperbuat jarimah walaupun tidak ada persepakatan untuk itu sebelumnya, seperti memberikan persembunyian bagi orang yang berbuat maksiat.

\section{DAFTAR PUSTAKA}

Ali. Zainuddin, (2009), Hukum Pidan Islam. Jakarta:Sinar Grafika.

Al -Mawardi, (1966) Al Ahkam Al Shulthaniyyah (Beirut: Dar Al Fikr).

Badruzaman, D. (2019) Kajian Hukum Tentang Internet Mobile dalam Upaya Pencegahan Dampak Negatif Teknologi Informasi dan Komunikasi di Indonesia. Ajudikasi: Jurnal Ilmu Hukum, 3(2). 135-152.

Badruzaman, D., \& Ropei, A. (2020). Gender Equality For Women Victims Of Violence In Household. Al-IHKAM: Jurnal Hukum Keluarga Jurusan Ahwal AlSyakhshiyyah Fakultas Syariah IAIN Mataram,12(1), 1-14. https://doi.org/10.20414/alihkam.v12i1.2141

Bonger W.A, (1995), Pengantar Tentang Kriminologi. Jakarta :PT. Pembangunan.

Basri .C.H, (2008), Penuntun Penyusunan Rencana Penelitian dan Penulisan Skripsi (Bidang Ilmu Agama Islam). Jakarta :PT. Raja Grafindo Persada.

Djamil. F, (1997), Filsafat Hukum Islam.Jakarta: Ciputat: Logos Wacana Ilmu.

Djazuli.A (1993) .Imu Fiqh (Sebuah Pengantar). Bandung : Orba sakti.

Gaos A.H (2006). Dasar-Dasar Fiqh Jinayah. Bandung: CV. Insan Mandiri,

Hakim. Rahmat, (2000), Hukum Pidana Islam (Fiqh Jinayah). Bandung :CV. Pustaka Setia.

J.M. Bemelen,(1968), Hukum Pidana 3:bagian Khusus Delik-delik Khusus Bandung: Binacipta.

Maslani, (2009), Masail Fiqhiyah Al-Hadisyah (fiqih kontemporer). Bandung: :Sega Arsy.

Moeljatno, (2003), Asas-Asas Hukum Pidana. Jakarta :PT. Rineka Cipta. 
TAHKIM, Jurnal Peradaban dan Hukum Islam. Vol.3 No.2 (0ktober, 2020) | ISSN : 2597-7962

Moeljatno, (2006), KUHP (kitab undang-undang hukum pidana). Jakarta: PT Bumi Aksara.

Mubarok. Jaih, (2005)Kaidah Fiqh Jinayah (Asas-Asas Hukum Pidana Islam). Bandung :Pustaka Bani Quraisy.

Muslich Ahmad Wardi. (2003).Hukum Pidana Islam .Jakarta: Sinar Grafika.

M.Zein. S. E, (2005) Ushul Fiqih, cetakan 1. Jakarta:Kencana.

Prodjodikoro. W,(1986), Tindak-tindak pidana tertentu di indonesia, Bandung: PT. Eresco.

Rosyada. D, (1995) Hukum islam Dalam Pranata Sosial. Jakarta: Rajawali Pers.

R.Soeroso, (2006), Pengantar Ilmu Hukum. Jakarta :Sinar Grafika.

Syarifuddin Amir. (2003). Garis-Garis Besar Fiqh. Jakarta: Prenada Media. 